\title{
INOVACIJOMS PALANKIOS IŠORINĖS VERSLO APLINKOS VEIKSNIAI LIETUVOJE, SKATINANTYS „BORN GLOBAL“ İMONIŲ ATSIRADIMĄ
}

\author{
Ramūnas Časas ${ }^{1}$, Vilma Dambrauskaitè ${ }^{2}$ \\ Vilniaus universitetas, Sauletekio al. 9, LT-10222 Vilnius, Lietuva \\ El.paštas: ${ }^{1}$ ramunas.casas@ef.vu.lt; ${ }^{2}$ vilma.dambrauskaite@gmail.com
}

Iteikta 2011-04-02; priimta 2011-09-05

\begin{abstract}
Santrauka. Šio straipsnio tikslas - nustatyti, kokios inovatyvumą skatinančios išorinès verslo aplinkos charakteristikos yra palankios šiuolaikinėms globalioms „Born Global“ įmonėms, t. y. turi įtakos jų atsiradimui. Apžvelgus teorinius šaltinius, išskiriama 16 tokių išorinès verslo aplinkos charakteristikų. Apklausus 50 Lietuvos „Born Global“ imonių, nustatyta, kad visos identifikuotos išorinès verslo aplinkos charakteristikos, lemiančios inovatyvumą, skatina Lietuvos „Born Global“ i̇monių atsiradimą, tačiau tik trys iš jų būdingos išorinei Lietuvos verslo aplinkai.
\end{abstract}

Reikšminiai žodžiai: „Born Global“ įmonès, išorinè verslo aplinka, inovacijos, nacionalinio inovacijų pajègumo modelis.

\section{FACTORS OF THE INNOVATION-FRIENDLY EXTERNAL BUSINESS ENVIRONMENT IN LITHUANIA, PROMOTING THE EMERGENCE OF THE “BORN GLOBAL” COMPANIES}

\author{
Ramūnas Časas ${ }^{1}$, Vilma Dambrauskaitè ${ }^{2}$ \\ Vilnius University, Sauletekio al. 9, LT-10222 Vilnius, Lithuania \\ E-mails: ${ }^{1}$ ramunas.casas@ef.vu.lt (corresponding author); ${ }^{2}$ vilma.dambrauskaite@gmail.com \\ Received 2 April 2011; accepted 5 September 2011

\begin{abstract}
The article seeks to identify the external business environment factors affecting today's global business, "Born Global", as a whole. It was found that the main features of the distinctness of these companies are their rapid internationalization, innovation management, and entrepreneurship. Further, the article explores the characteristics of the external business environment, which encourage innovation and are favourable to the performance of the "Born Global" companies. A review of theoretical sources identifies 16 of these external business environment characteristics. 50 interviews with Lithuanian "Born Global" companies have confirmed that all the identified characteristics of the external business environment, leading to innovation, promote Lithuanian "Born Global" companies, but only three of them are specific to the external business environment in Lithuania.
\end{abstract}

Keywords: Born Global companies, external business environment, innovation, national model for innovation capacity.

JEL Classification: F23, M13, F18, Q51, Q55, O32. 


\section{Ivadas}

Per pastaruosius kelis dešimtmečius tarptautinio verslo aplinka smarkiai pasikeitè: pagerėjo transporto infrastruktūra, patobulèjo gamybos procesas, sumažèjo prekybos barjerai, tapo efektyvesnè įmonių komunikacija, padaugèjo žmonių, turinčių tarptautinio verslo patirties (Gabrielsson et al. 2004; Oviatt, McDougall 1994; Rasmussen, Madsen 2002). Visi šie pokyčiai suteikè įmonèms daugiau galimybių internacionalizuoti verslą, veikti užsienio rinkose ir atitinkamai paskatino „Born Global“ įmonių atsiradimą. Neretai „Born Global“ imonès mokslininkų ìvardijamos kaip internacionalizacijos fenomenas, nes jos yra išskirtinès, paneigiančios iki tol vyravusị suvokimą, jog įmonès per palyginti ilgą laiką, tik sukūrusios stiprią poziciją vietinèje rinkoje, palaipsniui turi vykdyti internacionalizaciją. Kitaip sakant, greita ir intensyvi internacionalizacija suvokiama kaip pagrindinis „Born Global“ įmonių bruožas.

Jau daugiau nei 30 metų i̇monių internacionalizacijos procesas yra viena populiariausių visame pasaulyje tyrimų tema. Susidomèjimas šia sritimi grindžiamas augančia tarptautinès prekybos svarba, kuri yra tiesiogiai susijusi su besikeičiančia išorine verslo aplinka, atspindinčia vieną pagrindinių šiuolaikinès aplinkos tendencijų - globalizaciją (Rasmussen, Madsen 2002; Gabrielsson, Kirpalani 2004; Andersson, Wictor 2003). Daugelis iki XX a. paskutinio dešimtmečio atliekamų tyrimų buvo paremti tradicinèmis internacionalizacijos teorijomis, tokiomis kaip produkto gyvavimo ciklo teorija, monopolistinio pranašumo teorija, oligopolistinès reakcijos teorija, Uppsala internacionalizacijos modelis (Johanson, Vahlne 1977), inovacijomis pagristas modelis (Gankema et al. 2000), internacionalizacijos tinklo modelis (Lampa, Nilsson 2004: 28-41) ir kt. Tradicinèse internacionalizacijos teorijose aiškinama, kad įmonès eksporto veiklos plètra yra laipsniškas ir nuoseklus procesas, kai pradžioje prekès eksportuojamos ị fiziškai artimas šalis, o vèlesniais etapais veikla perkeliama ị tolimesnes rinkas. Vis dèlto prieš porą dešimtmečių buvo pastebèta, kad įmonių, kurios nesilaiko tradicinių internacionalizacijos stadijų, t. y. savo veiklą užsienio rinkose pradeda tik ịsikūrusios arba netrukus po įsikūrimo, daugèja (Rialp et al. 2005). Šis išskirtinumas, t. y. savitas verslo plètojimo būdas, leidžia tokias įmones įvardyti kaip internacionalizacijos fenomeną, tačiau pastebèta, kad dažniausia mokslinejje literatūroje jos yra vadinamos „Born Global“ i̇monèmis.

Pirmą kartą „Born Global“ sąvoka buvo pavartota 1993 m. McKinsey\&Co ir M. W. Rennie Australijos pramonès tarybai (angl. The Australian Manufacturing Council) parengtame pranešime (Rennie 1993), o 1994 m. T. Cavusgil, remdamasis minètu pranešimu, paraše pirmąji mokslini straipsnį apie šiuos naujo tipo eksportuotojus (Rasmussen, Madsen 2002). Po kelerių metų „Born Global“ i̇monèmis susidomèta kitose pasaulio šalyse: Airijoje, Izraelyje, Naujojoje Zelandijoje, Skandinavijos šalyse, Jungtinèse
Amerikos Valstijose (JAV) ir t. t. (Gabrielsson, Kirpalani 2004). Tai paaiškina, kodèl sąvoka „Born Global“ turi tiek daug sinonimų (Gabrielsson et al. 2008; Andersson, Wictor 2003; Madsen et al. 2000; McDougall et al. 2003): „skirtingų šalių autoriai vartoja įvairius terminus „Born Global“ ìmonèms įvardyti“ (Luostarinen, Gabrielsson 2006: 776). Toks susidomèjimas „Born Global“ koncepcija ir darbų šiu ¿̇monių išorinès verslo aplinkos klausimais trūkumas paskatino atlikti tyrimą, kurio tikslas - nustatyti, kokie Lietuvos išorinès aplinkos veiksniai, lemiantys inovatyvią įmoniu veiklą, kartu skatina ir „Born Global“ imonių atsiradimą. Tyrimo metodas - tiesiogine 50 Lietuvos „Born Global“ imonių apklausa. Anketinès apklausos būdu surinkta pirmine informacija buvo apdorota ir analizuota naudojant SPSS Statistics 17,0.

\section{2. „Born Global“ ịmonès ir jų ypatumai}

„Born Global“ i̇monès - tai ankstyvą internacionalizaciją vykdančios, vadovų verslumu ir orientacija ị inovacijas pasižyminčios, dažniausiai mažo arba vidutinio dydžio (Lampa, Nilsson 2004) ir ị aukštąsias technologijas orientuotos, specifinèse rinkų nišose veikiančios, globalią viziją, „<...> unikalių išteklių naudojimo ir prekių realizavimo skirtingose šalyse konkurencinį pranašumą turinčios <... " (Oviatt, McDougall 1994: 49) įmonès.

Pagrindiniai „Born Global“ bruožai, t. y. i̇monių naujumas ir veikimas tarptautiniu arba globaliu mastu, moksliniuose straipsniuose apibūdinami naudojant i̇monès amžiaus ir veiklos geografijos kriterijus (1 pav.).

Mokslininkai nesutaria, kaip apibrèžti naujos tarptautinès įmonès statusą: vieniems „Born Global“ - tai ne ilgiau kaip per trejus metus (Madsen et al. 2000), kitų mokslininkų nuomone - ne ilgiau kaip per dvejus metus (Rennie 1993; Luostarinen, Gabrielson 2006; Andersson, Wictor 2003) nuo įsteigimo internacionalizacijos procesą atliekančios įmonès. Vis dèlto nemaža dalis mokslininkų laikosi nuostatos, kad identifikuojant „Born Global“' neturètų būti naudojamas konkretus laiko parametras, nes ne kiekviena įmoné, susidurdama su ịvairiais èjimo ị užsienįi iššūkiais bei naujo produkto išleidimo į rinką problemomis, vienodai greitai su tuo susitvarko ir pradeda internacionalizaciją (Gabrielsson et al. 2008). Tokie internacionalizacijos fenomeno nustatymo kriterijai, kaip i̇moné per dvejus metus turi gauti $75 \%$ (Rennie 1993), 50 \% (Gabrielsson, Kirpalani 2004) ar $25 \%$ (Andersson, Wictor 2003) pajamų iš užsienio, taip pat nèra tinkami, nes kiekvienoje pasaulio šalyje aukštas eksporto mastas suprantamas skirtingai, o supratimas priklauso nuo verslo šakos, kurioje įmonè veikia, nuo šalies dydžio, ekonominių sąlygų, kultūrinių ypatumų, kaimyninių valstybių ir t. t. (Gabrielsson et al. 2008).

I klausimą, kodèl „Born Global“ įmonès vykdo tokią ankstyvą internacionalizaciją, moksliniuose darbuose aiškinama remiantis per pastaruosius dešimtmečius pasikeitusia 
Veiklos geografija

\begin{tabular}{|c|c|c|}
\hline & Vietinè rinka & Tarptautinè rinka \\
\hline Nauja ịmonè & & „Born Global“ ịmonės \\
\hline anizacijos amžius & & \\
\hline Sena ịmonè & & \\
\hline
\end{tabular}

1 pav. Pagrindiniai „Born Global“ įmonių bruožai (Oviatt, McDougall 1994: 48)

Fig. 1. The main features of "Born Globals" (Oviatt, McDougall 1994: 48)

ir toliau besikeičiančia išorine verslo aplinka: technologiju pažanga komunikacijų ir transporto sistemose, hiperkonkurencija, naujų rinkų nišų atsiradimas ir jų daugejjimas, vartotojų poreikių panašèjimas, darbo jègos mobilizavimasis ir tarptautinę patirtį turinčių vadovų gausèjimas, prekybos barjerų mažejimas bei tarptautinio finansavimo galimybių atsiradimas yra pagrindiniai išorinès verslo aplinkos pokyčiai, kuriuos galima skirstyti ț penkias stambias grupes (2 pav.), sudarančias prielaidas „Born Global“ i̇monems atsirasti (Gabrielsson et al. 2004; Oviatt, McDougall 1994; Rasmussen, Madsen 2002; Rialp et al. 2005).

Globalinių pokyčių daromą poveikị ịmonèms taip pat patvirtina L. Lindmark, P. R. Christense, H. Eskelinen ir kt. atliktas Europos šiaurès šalių įmonių tyrimas, kurio metu buvo nustatyta, kad kuo toliau, tuo labiau įmonès yra linkusios vykdyti internacionalizaciją iškart arba netrukus po i̇monès ịsteigimo (Madsen, Servais 1997: 564), nes išorinëje verslo aplinkoje vykstantys pokyčiai verčia įmones taikytis prie jų ir priimti naujus strateginius sprendimus (Rialp et al. 2005; Rasmussen, Madsen 2002), taip pat sukelia pokyčius įmonių viduje, pavyzdžiui, įmonès vadovo požiūrio ị valdymą pasikeitimas (Rasmussen, Madsen 2002; Kudima et al. 2008).

Be ankstyvos internacionalizacijos vykdymo, kitas labai svarbus „Born Global“ įmonių bruožas yra inovacijų vykdymas, t. y. investavimas ị naujoves ir modernios technologijos naudojimas, nes tai leidžia rinkai pasiūlyti unikalių, novatoriškų ir itin specializuotų prekių (Gabrielsson et al. 2008; Andersson, Wictor 2003; Madsen, Servais 1997). Tai, kad „Born Global“ imonès vykdo inovacijas, patvirtina ir A. Rialp ir J. Rialp (2006) atlikto tyrimo rezultatai, kurie parodè, kad net 81,4 \% „Born Global“ i̇monių investuoja i tyrimus ir vystymą (Rialp, A., Rialp, J. 2006: 76). „Born Global“ įmonès vykdo inovacijas, nes tai leidžia joms konkuruoti aukšta kokybe ir prekių diferencijavimu, taip išvengiant tiesioginès konkurencijos su stambiomis įmonèmis (Kudima et al. 2008; McDougall et al. 2003). Kitaip sakant, „Born Global“ imonių konkuravimas grindžiamas ne kaina, o unikalių žinių ir technologijų, kurias konkurentams yra sunku nukopijuoti, turejjimu ir naudojimu, leidžiančiu vartotojams pasiūlyti didesnę pridètinę vertę turinčių prekių (Kudima et al. 2008; McDougall et al. 2003; Madsen et al. 2000; Bell, McNaughton 2000).

Trečiasis „Born Global“ įmonių išskirtinumą lemiantis bruožas - jų steigejeu ar vadovų verslumas, nes šių i̇monių steigèjai ir (arba) vadovai - tai verslumu pasižymintys verslininkai, nebijantys prisiimti rizikos, iniciatyvūs ir inovatyvūs (Gabrielsson et al. 2008; Bell, McNaughton 2000). Be šių verslumo savybių, reikalingų internacionalizacijai ir inovacijoms vykdyti, tarptautine patirtis taip pat yra priskiriama prie „Born Global“ imonių steigèjų ir (arba) vadovų verslumo savybių, nes tarptautiné patirtis, igyta gyvenant, mokantis ar dirbant užsienyje (Madsen, Servais 1997:567), leidžia: pirma, lengviau identifikuoti atsirandančias galimybes; antra, sumažejus neapibrěžtumui, vykdyti greitesnę internacionalizaciją (McDougall et al. 2003: 62); trečia, naudojantis asmeninių ryšių tinklu ir kultūrinių skirtumų išmanymu, kurti tarptautinius santykius su ịvairiomis užsienio įmonèmis (Oviatt, McDougall 1995) bei vykdyti internacionalizaciją ne pagal tradicini geografinị rinkų parinkimo modelị („ratilai vandenyje“), o pagal turimus ryšius su potencialiais vartotojais (Madsen, Servais 1997: 567), kurie dažniausia būna ne fiziniai, o juridiniai asmenys (Luostarinen, Gabrielsson 2006: 786); ketvirta, tarptautinès patirties turejjimas skatina įmonių steigèjų ir (arba) vadovų globalaus požiūrio susiformavimą (Lampa, Nilsson 2004; Madsen, Servais 1997).

Nors „Born Global“ i̇monių konkurencingumui yra svarbi ankstyva internacionalizacija, „Born Global“ imonių steigèjo ir (arba) vadovo verslumas bei jų inovatyvumas, t. y. inovacijų vykdymas, šiame straipsnyje apsistojama tik prie paskutinio veiksnio: tiriami inovacijoms palankios išorinės verslo aplinkos veiksniai, turintys ịtakos „Born Global“ imonių atsiradimui, bei laikomasi prielaidos, kad jei išoriné verslo aplinka yra palanki inovacijoms, tai ji yra palanki ir „Born Global“ itmonių atsiradimui. 


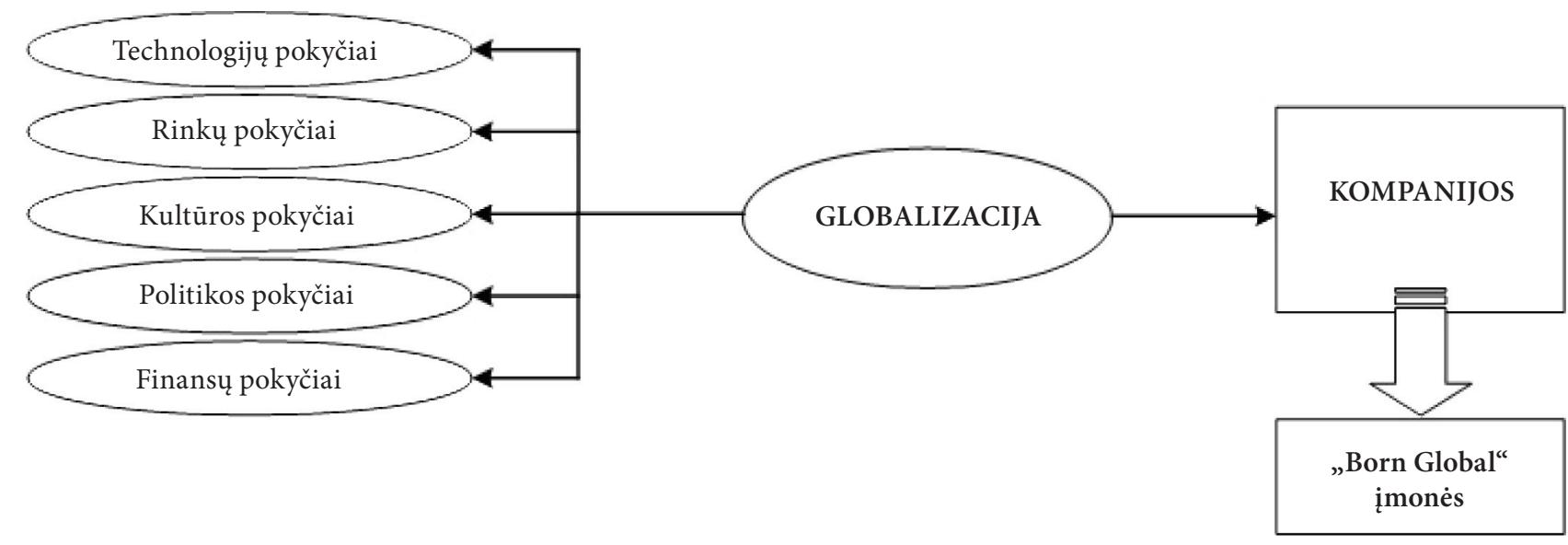

2 pav. Išorinès verslo aplinkos pokyčiai, paskatinę „Born Global“ imonių atsiradimą (pagal Oviatt, McDougall 1994; Madsen, Servais 1997; Gabrielsson et al. 2004)

Fig. 2. Changes in the external business environment that had determined the emergence of the "Born Global" companies (Oviatt, McDougall 1994; Madsen, Servais 1997; Gabrielsson et al. 2004)

\section{Inovacijoms palankios išorinės verslo aplinkos veiksniai}

Ilgą laiką daugelis įmonių savo konkurencinius pranašumus grindè žemesnèmis sąnaudomis ir aukštesne kokybe, tačiau globalizacija ir dèl jos auganti tarptautinè konkurencija priverte pasitelkti sudètingesnius ir konkurentams sunkiau nukopijuojamus, inovacijomis grindžiamus konkurencinius pranašumus (Porter, Stern 2001).

Atsižvelgiant ị tai, kad „Born Global“ imonès prekiauja unikaliomis, specializuotomis, klientų specifinius poreikius tenkinančiomis prekèmis, t. y. konkuruoja naudodamos diferencijavimo strategiją, galima drąsiai teigti, kad inovacijos yra neatskiriama šių i̇monių veiklos dalis. Internacionalizacijos fenomeno orientacija $\mathfrak{i}$ inovacijas leidžia igyti ilgalaikị konkurencini pranašumą ir tvirtą poziciją konkrečiame aukštųjų technologijų verslo šakos rinkos segmente (Porter 1990), kitaip sakant, „Born Global“ ¿̇monių konkurencingumas priklauso nuo inovacijų vykdymo, o tam, kad būtų vykdomos inovacijos, reikalingi jų vykdymą skatinantys veiksniai. Paprastai pirmiausia tokiu atveju akcentuojami tokie vidiniai inovacijas skatinantys veiksniai, kaip įmonès gebejjimai ir i̇monèje vykdomi technologijų kūrimo bei komercinio pritaikymo procesai, tačiau inovacijoms ne mažiau svarbi yra ir išorinè verslo aplinka (Porter, Stern 2001: 28). Pavyzdžiui, Izraelyje veikiančiu i̇monių inovacijų vykdymo mastas yra didelis ne vien dèl efektyvaus technologijų valdymo, bet ir dèl to, kad Izraelio išorinè verslo aplinka yra palanki inovacijoms: stiprus universitetų tinklas ir didelis aukštajj išsilavinimą bei patirtị turinčiu mokslininkų ir inžinierių skaičius (Porter, Stern 2001:28). Taigi įmonių polinkis vykdyti inovacijas priklauso ne tik nuo vidinių veiksnių, bet ir nuo šalies ar verslo šakos, kurioje veikia įmonès, išorinès verslo aplinkos, todèl analizuojant „Born Global“ ịmonèms atsirasti palankią išorinę verslo aplinką, būtina identifikuoti inovacijų vykdymą skatinančius išorinès verslo aplinkos veiksnius.

Du mokslininkai, M. E. Porter ir S. Stern, tyrinèdami inovacijų tarp įvairių pasaulio šalių skirtumus, nustatè, kad įmonių polinkis ị inovacijas priklauso nuo vietos, kurioje tos įmonès veikia, išorinès verslo aplinkos. Jų nuomone, bet kurios vietos išorinès verslo aplinkos tinkamumą inovacijoms atspindi nacionalinis inovacijų pajegumas, kuris suprantamas kaip šalies potencialas, t. y. „<...> politinis ir ekonominis vientisumas, leidžiantis gaminti komerciškai susijusias inovacijas" (Porter, Stern 2001: 29). Šie mokslininkai, apibendrinę savo atliktų tyrimų rezultatus, suformavo modelį, rodantị nacionalinio inovacinio pajègumo, leidžiančio šaliai konkuruoti globaliu mastu, šaltinius (3 pav.).

Galima teigti, kad bet kokios šalies nacionalinio inovacijų pajègumo šaltiniai yra:

1. Klasteris ir specifinè inovaciju aplinka - tai inovacijas kuriančios ir jas komerciškai pritaikančios imonès. Pastebèta, kad inovacijos kuriamos ir komerciškai pritaikomos dažniausia klasteriuose, kurių specifinè inovacijų aplinka gali būti pavaizduota, remiantis „Nacionalinio deimanto“ modeliu. Inovacijoms vykdyti klasteriai gimtojoje šalyje yra svarbus išorinès verslo aplinkos veiksnys, nes įmonès, būdamos klasterio dalyvès, igyja pranašumą identifikuodamos inovacijų poreikį ir jų galimybes, o klasterio lankstumas ir pajègumas leidžia daug greičiau naujas idejjas paversti realybe.

2. Ryšio kokybe - tai abipusis ryšys tarp bendros inovacijų infrastruktūros bei klasterio ir specifinès 


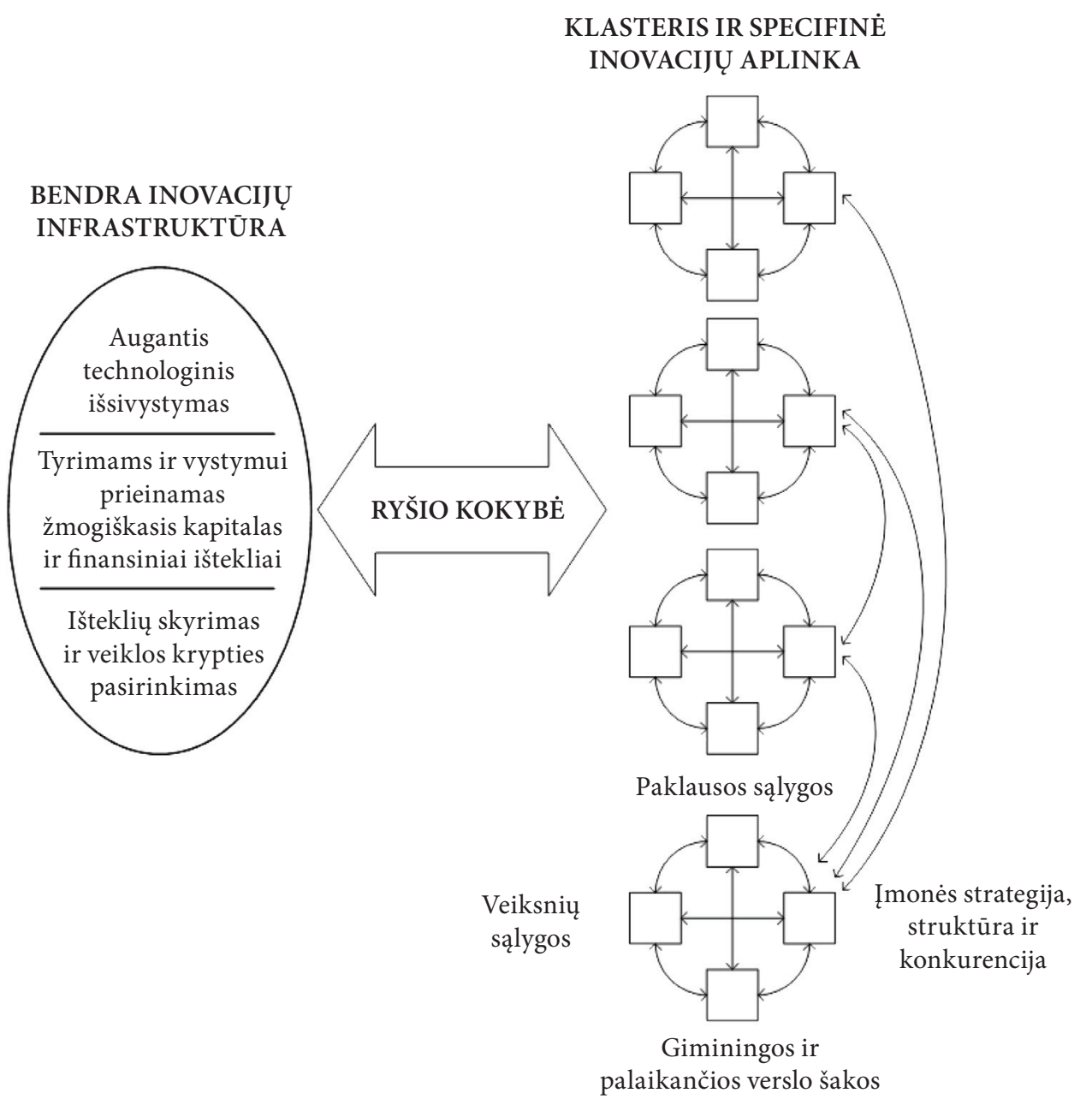

3 pav. Nacionalinio inovacijų pajėgumo modelis (Porter, Stern 2001: 29)

Fig. 3. Model of the national innovation capacity (Porter, Stern 2001: 29)

inovacijų aplinkos: stiprūs klasteriai maitina bendrą inovacijų infrastruktūrą ir gauna iš jos naudos. Iš tikrųjų tam tikros vietos nacionalinis inovacijų pajègumas labai stipriai priklauso nuo ryšio kokybès, kurị sudaro daugybė formalių ir neformalių organizacijų bei tinklų: ịvairios bendradarbiavimo institucijos, pavyzdžiui, šalies universitetų sistema, yra viena svarbiausių institucijų, jungiančiu klasterius su inovacijų infrastruktūra, taip pat rizikos kapitalą teikiančiu organizacijų tinklas ir kiti tinklai. Nesant stipraus abipusio ryšio, kyla grèsmė, kad mokslo ir technologijų inovacijos greičiau pasklis kitose pasaulio šalyse, negu bus panaudotos gimtosios šalies ìmonèse.

Taigi bet kokios šalies išorinès verslo aplinkos palankumą inovacijoms rodo nacionalinis inovacijų pajègumas, kuris keičiasi priklausomai nuo bendros inovacijų infrastruktūros, klasterio ir specifinès inovacijų aplinkos ir ypač nuo pirmųjų dviejų tarpusavio ryšio kokybès, kitaip sakant, visi trys nacionalinio inovacijų pajègumo šaltiniai formuoja imonių, taip pat ir „Born Global“, galimybes vykdyti globalaus masto inovacijas (Porter, Stern 2001: 29). Tuo remiantis galima daryti išvadą, kad ịvertinus visus tris nacionalinio inovaciju pajègumo šaltinius, galima nustatyti ir palyginti ịvairiu šalių išorinès verslo aplinkos palankumą inovacijoms bei atitinkamai „Born Global“ imonių atsiradimui.

Nacionalinį inovacijų pajègumo modelị suformavusių mokslininkų nuomone, tam tikros vietos inovacijų aplinkos sąlygas, t. y. nacionalinis inovacijų pajegumą, geriausiai parodo inovacijų rezultatas - naujų patentų skaičius per metus, tenkantis tūkstančiui gyventojų. Šis indeksas leidžia ne tik įvertinti, bet ir palyginti skirtingų vietų inovacijų aplinką: kuo didesnis patentų skaičius, tuo labiau galima daryti išvadą, kad tos vietos išorinè verslo aplinka yra palankesnè inovacijoms. Be nacionalinị inovacijų pajègumą matuojančio indekso, taip pat buvo išskirtos ir visų trijų nacionalinio inovacijų pajègumo šaltinių matavimo priemonès, leidžiančios ịvertinti, kokia yra tam tikros vie- 
tos bendra inovacijų infrastruktūra, klasterio ir specifinè inovacijų aplinka bei ryšio kokybè (4 pav.).

4 pav. pateiktos matavimo priemonès leidžia ne tik išmatuoti ir palyginti skirtingų vietų aplinkos palankumą inovacijoms, bet ir identifikuoti inovacijoms bei atitinkamai „Born Global“ imonių atsiradimui įtaką darančius gimtosios šalies išorinès verslo aplinkos veiksnius.

Mokslininkų ir inžinierių dalis nuo visų dirbančiųų, bendros (tiek viešojo, tiek privačiojo sektoriaus) šalyje tyrimams ir vystymams skiriamos lěšos, aukštajam išsilavinimui skiriamų lěšų dalis nuo BVP, universitetuose atliekamų tyrimų ir vystymo dalis nuo visų šalyje vykdomų inovacijų, savarankiškai veikiančios mokslo laboratorijos ir institutai tai žinių ištekliai.

Bendros (tiek viešojo, tiek privačiojo sektoriaus) šalyje tyrimams ir vystymams skiriamos lèšos, mokesčių politika inovacijų atžvilgiu - tai finansinès paramos inovacijas vykdančioms įmonèms teikimas (paramos fondai, mokestinès lengvatos, paskolu garantijos ir draudimas), pavyzdžiui, Lietuvos Respublikos Vyriausybès ịkurtas Lietuvos valstybinis mokslo ir studijų fondas, negrąžintinų paskolų teikimas, pelno mokesčio lengvata mokslinių tyrimų ir eksperimentinès plètros (MTEP) veiklą vykdančioms įmonèms (Inovacijų portalas 2009).

Intelektinio turto apsauga ir jos efektyvumas - tai istatymai ir taisyklès, igyvendinantys intelektinio turto apsaugą.

Šalies ekonomikos atvirumas tarptautinei prekybai ir investicijoms - tai atvira šalies ekonomika ir šalies vyriau- sybės vykdoma tiesioginių užsienio investicijų pritraukimo politika, skatinanti ir pritraukianti užsienio investicijas.

Antimonopoliniai veiksmai, skatinantys įmones konkuruoti inovacijomis - tai šalyje veikiantys antimonopoliniai įstatymai bei taisyklès. Vis dèlto šis išorinès verslo aplinkos veiksnys nedaro ittakos „Born Global“ i̇monių atsiradimui, nes, kaip jau buvo minèta, „Born Global“ i̇monès inovacijas vykdo siekdamos ne konkuruoti, o išvengti tiesioginès konkurencijos su kitomis įmonemis.

Rodiklis BVP vienam gyventojui, bendros šalyje tyrimams ir vystymams skiriamos lèšos, privačiojo sektoriaus tyrimams ir plètotei skiriamos lèšos, šalies technologinio specializavimosi laipsnis - tai šalies technologinis išsivystymas, darantis ịtaką inovacinès veiklos aktyvumui.

Rizikos kapitalą teikiančių ịmonių tinklas šalyje - tai rizikos kapitalą teikiančių įmonių egzistavimas šalyje, kitaip sakant, bendra inovacijų infrastruktūra sujungiama su specifine ir inovacijų aplinka, jei įmonès, vykdančios inovacijas, gali pasinaudoti šalyje esančiais finansinio kapitalo ištekliais.

Universitetuose atliekamų tyrimų ir vystymo dalis nuo visų šalyje vykdomų inovacijų - tai universitetų šalyje egzistavimas, o bendra inovacijų infrastruktūra sujungiama su specifine ir inovacijų aplinka, jei ịmonés palaiko ryšius ir bendradarbiauja su šalyje esančiais universitetais.

Savarankiškai veikiančios mokslo laboratorijos ir institutai - tai mokslo laboratorijų ir institutų šalyje egzistavimas, o bendra inovacijų infrastruktūra sujungiama su specifine ir inovacijų aplinka, jei įmonés palaiko ryšius ir

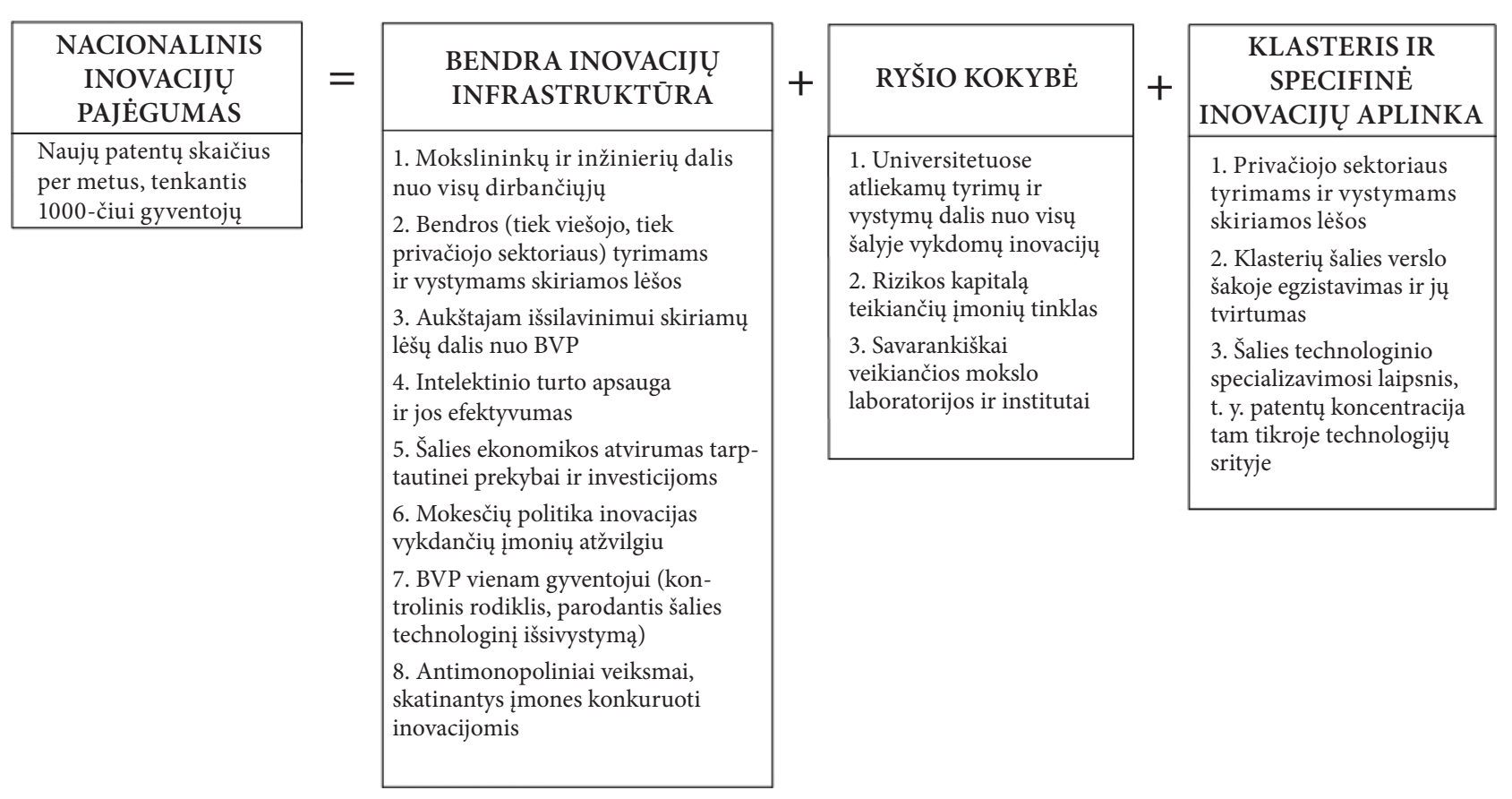

4 pav. Technologinėms inovacijoms palankios išorinės verslo aplinkos matavimo priemonès (Porter, Stern 2001: 29-32, 35)

Fig. 4. Tools for measuring the technological innovation-friendly external business environment (Porter, Stern 2001: 29-32, 35) 
bendradarbiauja su šalyje esančiais mokslo institutais bei tyrimų centrais. Pavyzdžiui, Kauno technologijos universiteto Aplinkos inžinerijos institutas bei Vaizdo apdorojimo ir analizès laboratorija, Lietuvos biomedicininès inžinerijos draugija ir kt.

Klasterių šalies verslo šakoje egzistavimas ir jų tvirtumas - tai klasterių šalies verslo šakoje egzistavimas ir (arba) jų formavimasis.

Nacionalinio inovacijų pajègumo šaltinių matavimo priemonès leidžia prognozuoti tam tikros vietos inovaciju atžvilgiu išorinès verslo aplinkos pokyčius ateityje bei atitinkamai „Born Global“ imonių atsiradimui ateityje tiksiančias vietas. Pavyzdžiui, 1996 m. Italijoje, Ispanijoje ir Japonijoje pragyvenimo lygiai buvo labai panašūs, tačiau iš šių trijų šalių didžiausią mokslininkų ir inžinierių dalị tarp visų dirbančiųjų turèjo Japonija (Porter, Stern 2001: 31), dèl to Japonija yra ịvardijama kaip inovacijų šalis, nes joje yra išplettota tiksliųjų mašinų ir prietaisų, elektrotechnikos ir elektronikos įrenginių, pramoninių ir buitinių robotų gamyba, taip pat automobiliu, lèktuvų, geležinkelio įrenginių gamyba, laivų statyba, tekstilès ir chemijos pramonés.

Be nacionalinio inovacijų pajègumo modelio, išskiriami ir kiti išorinés verslo aplinkos veiksniai, darantys ịtaką imonių gebejjimui vystyti ir vykdyti inovacijas bei „Born Global“ imoniu atsiradimui. Visu pirma tai ekonominio paskatinimo mechanizmas - paklausos egzistavimas gimtosios ir (arba) užsienio šalių rinkose (Bessant, Tidd 2007). Remiantis M.E. Porter, inovacijoms įtaką turi „profesionalių“ vartotojų paklausa, paklausos dydis ir jos augimo tempas, nepriklausomų pirkèjų skaičius bei ankstyva paklausa. Vis dèlto atsižvelgiant į tai, kad „Born Global“ įmonès inovacijas vykdo siekdamos ne konkuruoti, o išvengti tiesioginès konkurencijos su kitomis įmonèmis, t. y. siekdamos diferencijuoti prekes, galima daryti išvadą, kad šiuo atveju tik „profesionalių"vartotojų paklausa ir ankstyvoji paklausa, kuri palengvina visiškai naujų ar modifikuotų prekių išleidimą i rinką bei, kaip ir „profesionalūs"vartotojai, leidžia ịmonèms numatyti naujus, plačiai tarp vartotojų pasklisiančius poreikius, turi itakos „Born Global“ imonių atsiradimui. Kitas ekonominio paskatinimo mechanizmas - intensyvi konkurencija gimtosios ir (arba) užsienio šalių rinkose - taip pat yra inovaciju vykdymą, tiek siekiant konkuruoti, tiek išvengti tiesioginès konkurencijos, skatinantis išorinès verslo aplinkos veiksnys (Bessant, Tidd 2007). Vis dèlto būtina pažymèti, kad „Born Global“ imonès, vykdydamos veiklą globalių rinkų nišose, susiduria su palyginti maža konkurencija gimtojoje šalyje, kitaip sakant, „Born Global“ imonès veikia aplinkoje, kurioje vyrauja globali konkurencija (Gabrielsson, Kirpalani 2004), todèl didžiausią poveikį inovacijoms daro ne gimtosios šalies, o užsienio šalių konkurencija tam tikroje verslo šakoje.

Antra, inovacijoms ittaką taip pat daro vyriausybès nustatomi ịvairūs reikalavimai, pavyzdžiui, aukšti produktų standartai, žemos aplinkos taršos ribos, nurodymai triukšmo atžvilgiu ir kt., ,verčiantys“ imones vykdyti inovacijas (Porter 1990: 585), ir, trečia, nefinansinès paramos įmonèms, vykdančioms tyrimus ir vystymą, teikimas, pavyzdžiui, inovacijų centrai, mokslo ir technologijų parkai, patentinès informacijos centras ir kitos organizacijos, teikiančios specializuotas paslaugas: inovacijų perdavimą ir partnerių paiešką, įmonių inovatyvumo nustatymą, informacijos ir konsultacijų teikimą ir t. t. (Inovacijų portalas 2009).

\section{Inovacijoms palankios išorinès verslo aplinkos veiksniai, turintys teigiamą ịtaką „Born Global“ ịmonių atsiradimui}

Jau minèta, kad „Born Global“ imonių verslo pagrindas inovatyvūs produktai ar sprendimai (Gabrielsson et al. 2008; Andersson, Wictor 2003), todèl apibendrinant inovacijoms palankios verslo aplinkos analizę, galima išskirti šešias veiksnių, turinčių teigiamą itaką „,Born Global“ imonių atsiradimui, grupes. Jos pateiktos 5 pav.

Žinoma, „Born Global“ imonès gali atsirasti ir tose vietose, kuriose išorinè verslo aplinka nèra palanki inovacijoms todèl, kad tyrimų ir vystymų veikla gali būti perkeliama į kitą ar kitas pasaulio šalis (Kudima et al. 2008: 41). Vis dèlto inovacijoms palanki gimtosios šalies išorinè verslo aplinka sukuria palankesnes sąlygas „Born Global“ imonèms atsirasti, nes tyrimai parodè, kad tų „Born Global“ imonių, kurios tyrimus ir vystymą atlieka gimtojoje šalyje, veiklos rezultatai yra geresni, lyginant su tomis „Born Global“ įmonèmis, kurios tyrimus ir vystymą atlieka užsienyje (Kudima et al. 2008: 41).

\section{Tyrimo metodologija}

Tyrimo tikslui - nustatyti, kokie Lietuvos išorinès verslo aplinkos veiksniai, lemiantys įmonių inovatyvią veiklą, paskatintų „Born Global“ imonių atsiradimą Lietuvoje iškelti trys tyrimo uždaviniai:

1. Nustatyti, kokie teorinès analizès metu identifikuoti „Born Global“ imonèse inovacijų vykdymą skatinantys išorinès verslo aplinkos veiksniai nedaro jokios įtakos Lietuvos „Born Global“ įmonių inovacijų vykdymui.

2. Nustatyti, kokie teorinès analizès metu identifikuoti „Born Global“ i̇monèse inovacijų vykdymą skatinantys išorinès verslo aplinkos veiksniai skatina Lietuvos „Born Global“ imones vykdyti inovacijas.

3. Nustatyti, kurie tyrimo metu identifikuoti Lietuvos „Born Global“ immonių inovacijas skatinantys išorinès verslo aplinkos veiksniai yra ir kurių nèra Lietuvos išorinejje verslo aplinkoje.

Tyrimo tikslui ir uždaviniams pasiekti buvo taikytas kiekybinis tyrimo metodas - anketine apklausa su klausimais ir atsakymų variantais, parengtais iš anksto. Anketa buvo platinama derinant internetinį anketos platinimo būdą su telefoninès ir asmeninès apklausos būdais (6 pav.). 


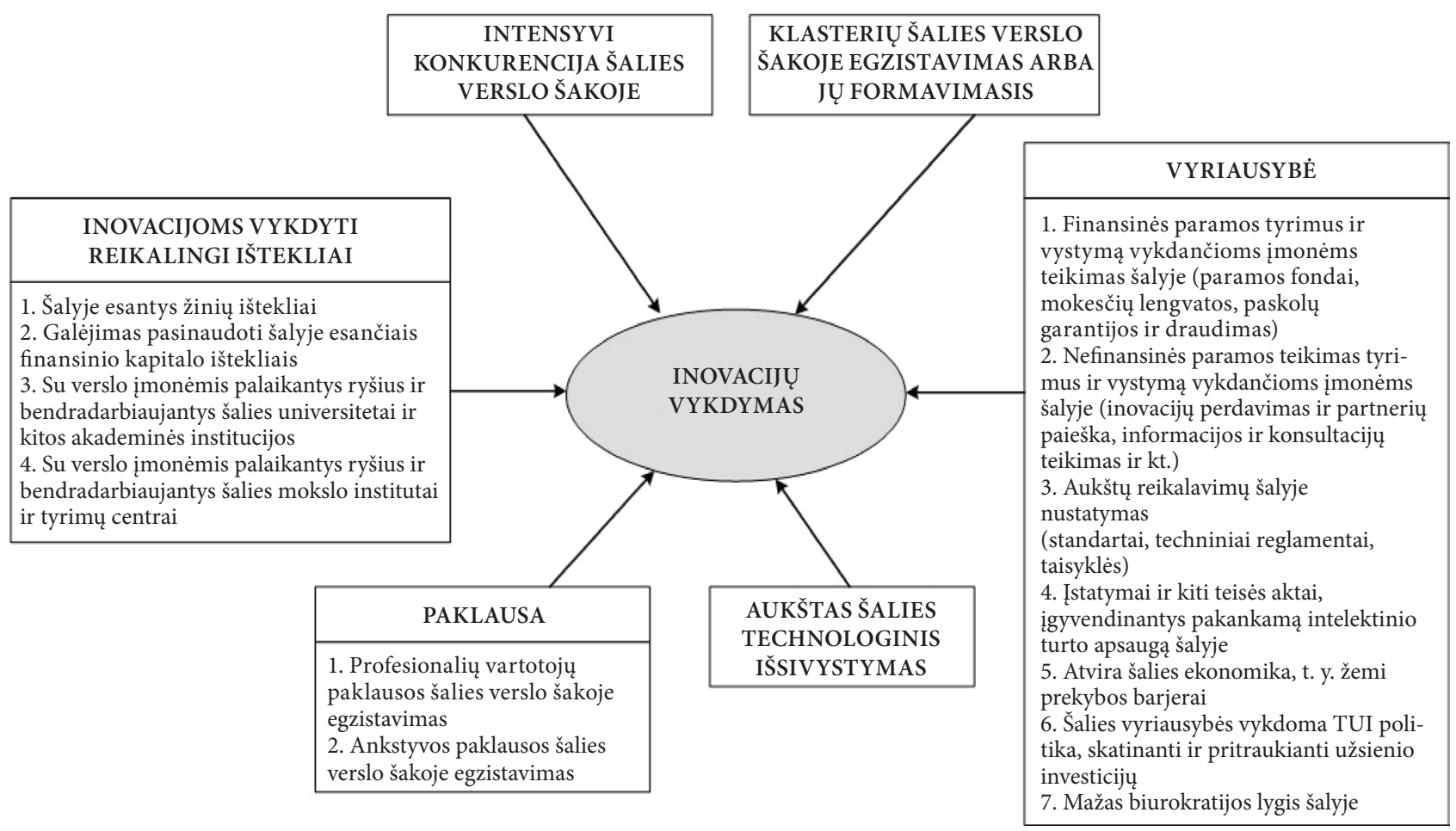

5 pav. Inovacijoms ịtaką darantys išorinès verslo aplinkos veiksniai

Fig. 5. Factors of the external business environment, which influence innovation

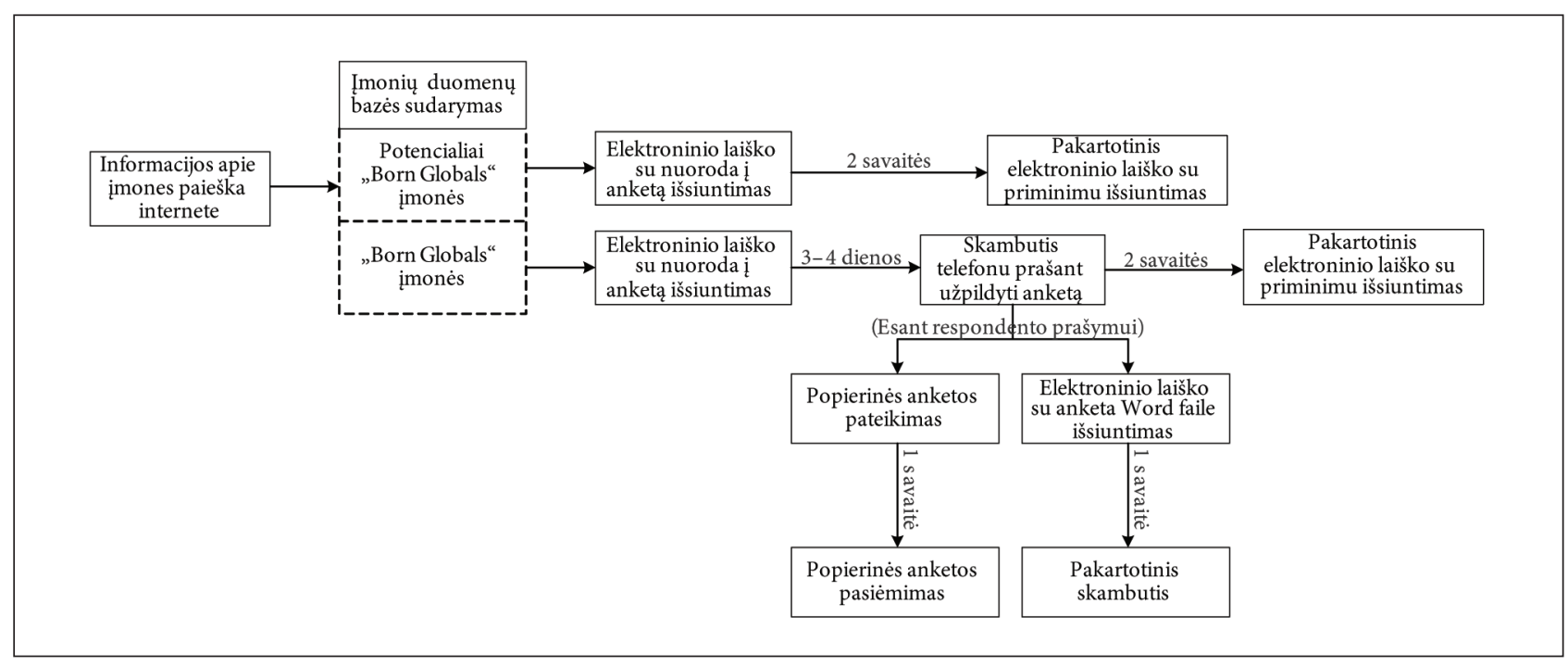

6 pav. Tyrimo eiga

Fig. 6. Research framework

Atlikto tyrimo priemonę - anketą - sudarè septyni klausimai. Buvo pateikti uždaro tipo klausimai, dichotominiai klausimai ir uždaro tipo klausimai su Likerto skale (nuo „visiškai sutinku“ - 5, iki „visiškai nesutinku“ - 1, nedaro jokios įtakos -0).
Pirmuoju anketos klausimu buvo siekiama išsiaiškinti, ar ịmonè gali būti priskiriama Lietuvos „Born Global“ įmonių kategorijai. Teirautasi:

1. Ar įmonès vadovas yra verslumu pasižymintis verslininkas. 
2. Ar įmonès veikimo laikotarpiu buvo kuriamos, vykdomos ar diegiamos inovacijos įmonès veikloje.

3. Ar įmonè per pirmus trejus metus nuo įmonès įsteigimo pradejo gauti $50 \%$ ir daugiau pajamų iš užsienio šalių rinkų, t. y. ar vykdè greitą ir intensyvią internacionalizaciją. Nepasirinkti griežtesni internacionalizacijos vykdymo kriterijai atsižvelgiant ì tai, kad nėra žinoma pagrindinẻ visuma, o $25 \%$ pajamų iš užsienio gavimo kriterijus nepasirinktas dèl to, kad internacionalizacijos vykdymas yra vienas iš „Born Global“ immonių bruožų.

4. Ar įmonè yra registruota Lietuvos Respublikoje.

Antrame anketos klausime buvo pateikiami teorinès analizès metu identifikuoti „Born Global“ imonèse inovacijų vykdymą skatinantys išorinès verslo aplinkos veiksniai ir prašoma respondentų nurodyti savo sutikimo arba nesutikimo laipsnị, kad:

1. Pateiktas išorinès verslo aplinkos veiksnys skatina imonę vykdyti inovacijas arba kad nedaro jokios įtakos.

2. Pateiktas išorinès verslo aplinkos veiksnys yra būdingas Lietuvai.

Trečiasis, ketvirtasis ir penktasis anketos klausimai buvo skirti išsiaiškinti, ar įmonè pagal ES rekomendacijoje dèl labai mažų, mažų ir vidutinių i̇monių sampratos (angl. European Union Commission Recommendation of 06/05/2003 concerning the definition of micro, small and medium-sized enterprises) nurodytus kriterijus gali būti priskirta labai mažų, mažų ir vidutinių įmonių kategorijai; šeštuoju anketos klausimu buvo siekiama išsiaiškinti, kokioje verslo šakoje veikia „Born Global“ immoné; septintuoju prašoma įrašyti anketą pildžiusio asmens užimamas įmonejje pareigas.

Atlikto tyrimo tiriamoji visuma yra visos Lietuvoje įsteigtos „Born Global“įmonès. Kadangi tikslus Lietuvos „Born Global“ imonių skaičius nèra žinomas, o jị nustatyti remiantis įmonių kataloguose, pavyzdžiui, „Visa Lietuva“ ar „Lietuvos įmonių katalogas", apie įmones pateikiama informacija yra neịmanoma, nuspręsta taikyti netikimybinès parankinès imties atrankos tyrimo metodą, o tai lèmé statistinị nereprezentatyvumą. Imties dydžiui nustatyti buvo taikomas lyginamuju tyrimų metodas, kai imties dydis nustatomas pagal panašiame tyrime dalyvavusių respondentų skaičių (Dikčius 2003: 128). Nors statistinei analizei atlikti turi būti apklausiama mažiausiai 30 respondentų (Saunders et al. 2007: 235), tačiau atsižvelgiant i tai, kad T. K. Madsen, E. Rasmussen ir P. Servais atliktame tyrime, kuris aprašytas straipsnyje „Differences and Similarities between Born Global and Other Types of Exporters" (Madsen et al. 2000), iš viso buvo apklaustos 47 „Born Global“ imonès, pasiriktas preliminarus planuojamas imties dydis - 50 anketą užpildžiusių Lietuvos „Born Global“ imonių.

\section{Rezultatai}

Po daugiau nei ménesị trukusio duomenų rinkimo iš viso buvo surinktos 108 užpildytos anketos, iš kurių 58 (arba $51,46 \%$ visų užpildytų anketų) buvo užpildytos ne Lietuvos
„Born Global“ i̇monių ir dèl to eliminuotos iš tolesnio tyrimo. Duomenų rinkimo etape buvo susiduriama su Lietuvos „Born Global“ įmonių radimo sunkumais, todèl pasiekus užsibrèžtą imties dydi - 50 Lietuvos „Born-Global“ imonių užpildytų anketų - duomenų rinkimas buvo sustabdytas.

\subsection{Respondentų charakteristika}

Remiantis ES rekomendacijoje dèl labai mažų, mažų ir vidutinių įmonių sampratos nustatytais labai mažų, mažų ir vidutinių immonių kriterijais, iš 50 šiame tyrime dalyvavusių Lietuvos „Born Global“ i̇monių 38 įmonès (arba 76 \%) yra priskiriamos labai mažų, mažų ir vidutinių i̇monių kategorijai, o likusios 12 įmonių (arba $24 \%$ ) - didelių i̇monių kategorijai.

Pagal priklausymą verslo sritims tyrime dalyvavusios Lietuvos „Born Global“ i̇monès pasiskirstè netolygiai (7 pav.).

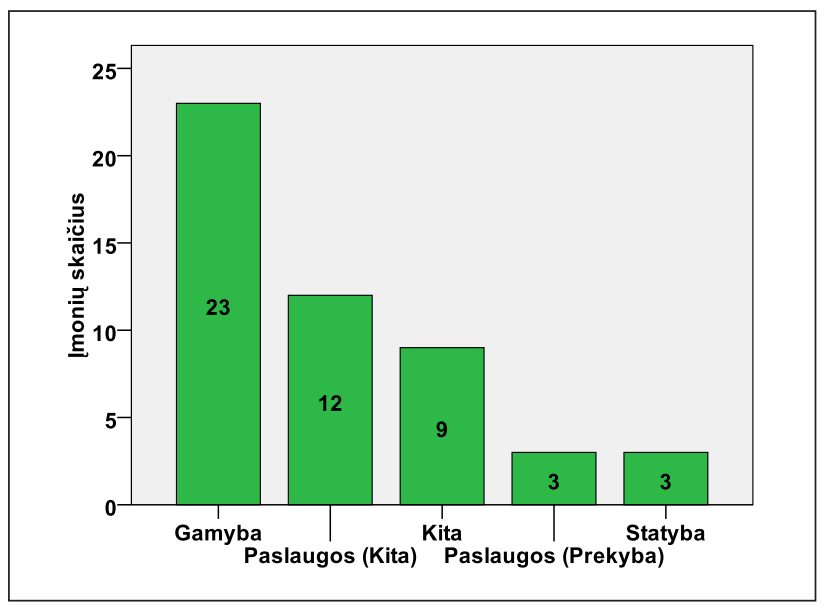

7 pav. Imoniu, kurioms atstovavo respondentai, verslo sritys

Fig. 7. Business sectors of the companies, represented by the respondents

I anketos klausimus daugiausia atsakè įmonių savininkai / akcininkai, aukščiausio ir vidutinio lygio vadovai (net $66 \%$ visų anketų), todèl galima daryti išvadą, kad duomenys apie Lietuvos „Born Global“ imonių išorinę verslo aplinką buvo surinkti iš kompetentingų asmenų.

\subsection{Lietuvos „Born Global“ ịmones supančios išorinès verslo aplinkos analizè}

Atsižvelgiant ị tai, kad tinkamai suformuota anketa leidžia pateikti geresnius ir patikimesnius mokslinio tyrimo rezultatus, prieš analizuojant respondentų atsakymus buvo patikrintas dviejų skalių - ar pateiktas išorinès verslo aplinkos veiksnys skatina vykdyti inovacijas ir ar tas išorinès verslo aplinkos veiksnys yra būdingas Lietuvai - vidinis 
patikimumas, apskaičiuojant Cronbacho alfos koeficientą (Vaitkevičius, Saudargienè 2006: 156). Atlikus skaičiavimus nustatyta, kad vidinis skalių patikimumas yra gana aukštas, nes pirmos skalès Cronbacho alfos koeficientas yra 0,875 , antros skalès - 0,841 .

Pirmasis tyrimo uždavinys - nustatyti, kokie teorinès analizès metu identifikuoti „Born Global“ įmones inovacijų vykdymą skatinantys išorinės verslo aplinkos veiksniai nedaro jokios ịtakos Lietuvos „Born Global“ įmonių inovacijų vykdymui. Šiam uždaviniui realizuoti buvo skaičiuojamas respondentų, pasirinkusių atsakymo variantą „Nedaro jokios įtakos", procentas kiekvieno išorinio verslo aplinkos veiksnio atžvilgiu (8 pav.).

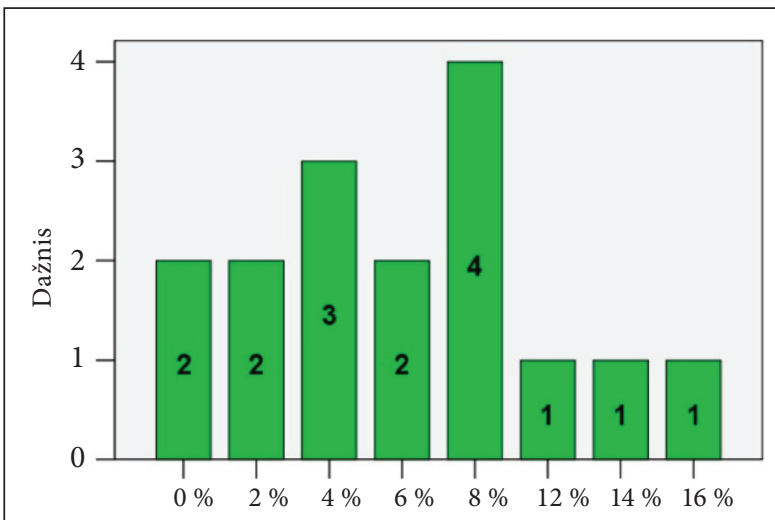

Konkretaus išorinès verslo aplinkos veiksnio atžvilgiu atsakymo „Nedaro jokios įtakos“ pasirinkusiųjų procentas

8 pav. Atsakymo „Nedaro jokios įtakos“ pasirinkusiųjų procentų dažniai

Fig. 8. Percental frequencies of the "No influence" answer

Atlikus šiuos skaičiavimus nustatyta, kad didžiausias respondentų, pasirinkusių atsakymo variantą „Nedaro jokios įtakos", skaičius buvo prie išorinès verslo aplinkos veiksnio „Su verslo įmonèmis palaikantys ryšius ir bendradarbiaujantys šalies mokslo institutai ir tyrimų centrai“. 8 (arba $16 \%$ ) respondentų nuomone, šis išorinès verslo aplinkos veiksnys nedaro jokios ịtakos inovacijų vykdymui (7 pav.). Atsižvelgiant į šiuos tyrimo rezultatus, galima teigti, kad didesnè tyrime dalyvavusių „Born Global“ įmonių dalis visus anketoje pateiktus išorinès verslo aplinkos veiksnius laiko įmonès inovacijų vykdymą skatinančiais išorinès verslo aplinkos veiksniais.

Visi respondentų atsakymai, kad tam tikras išorinès verslo aplinkos veiksnys „Nedaro jokios ittakos“, nebuvo įtraukti ị tolesnę Lietuvos „Born Global“ imonių atsiradimą skatinančių išorinès verslo aplinkos veiksnių analizę. Pabrěžtina, kad buvo eliminuoti tik konkretūs respondentų atsakymai, o kiti tų pačių respondentų atsakymai buvo ịtraukti ị tolesnę analizę.
Antram tyrimo uždaviniui „Nustatyti, kokie teorinès analizès metu identifikuoti „Born Global“ imonių atsiradimą skatinantys išorinès verslo aplinkos veiksniai skatina tyrimo metu apklaustas Lietuvos „Born Global“ įmones vykdyti inovacijas" igyvendinti buvo skaičiuojamas respondentų atsakymų Likerto skaleje aritmetinis vidurkis, o norint sužinoti, ar gautų vidurkių reikšmès skiriasi nuo vidurinès matavimo skalès reikšmès 3 , naudotas Stjudento $t$ statistinis kriterijus su nusistatytu 0,05 reikšmingumo lygmeniu.

Tyrimo rezultatai parodè, kad su $95 \%$ patikimumu galima teigti, kad visi teorinès analizès metu identifikuoti „Born Global“ įmonių atsiradimą skatinantys išorinès verslo aplinkos veiksniai skatina Lietuvos „Born Global“ imones vykdyti inovacijas, t. y. kiekvieno išorinès verslo aplinkos veiksnio atžvilgiu respondentų atsakymų vidurkis buvo didesnis už $3, o p \leq 0,05$.

Trečiam tyrimo uždaviniui „Nustatyti, kurie tyrimo metu identifikuoti Lietuvos „Born Global“ "imones inovacijas vykdyti skatinantys išorinės verslo aplinkos veiksniai yra ir kurių nẻra Lietuvos išorinëje verslo aplinkoje "igyvendinti buvo atliekami tokie patys skaičiavimai, kaip ir Lietuvos „Born Global“ i̇mones inovacijas vykdyti skatinančių išorinès verslo aplinkos veiksnių analizèje.

Remiantis tyrimo rezultatais, su $95 \%$ patikimumu galima teigti, jog 3 iš 16 tyrimo metu nustatytų Lietuvos „Born Global“ ịmones inovacijas vykdyti skatinančių išorinès verslo aplinkos veiksnių būdingi Lietuvos išorinei verslo aplinkai (vidurkis $>3, p \leq 0,05$ ), o 5 - nebūdingi (vidurkis $\leq 3$, $p \leq 0,05)(9$ pav.).

Dèl likusių 8 tyrimo metu nustatytų Lietuvos „Born Global“ įmonèse internacionalizaciją vykdyti skatinančių išorinės verslo aplinkos veiksnių pasakyti, ar išorinės verslo aplinkos veiksnys yra būdingas, ar nèra būdingas Lietuvos išorinei verslo aplinkai, negalima, nes nebuvo nustatytas statistiškai reikšmingas skirtumas tarp respondentų atsakymų vidurkio ir vidurinės matavimo skalès reikšmès 3 .

\section{Išvados ir praktinis tyrimo rezultatų naudojimas}

1. Visus teorinès analizès metu identifikuotus „Born Global“ imonių atsiradimą, t. y. inovacijų vykdymą, skatinančius išorinès verslo aplinkos veiksnius didesnè tyrime dalyvavusių Lietuvos „Born Global“ imonių dalis laiko jų atsiradimui, t. y. inovacijų vykdymui, įtaką darančiais išorinès verslo aplinkos veiksniais.

2. Tyrime dalyvavusių Lietuvos „Born Global“ imonių nuomone, Lietuvos išorinei verslo aplinkai būdingi šie trys Lietuvos „Born Global“ i̇mones inovacijas vykdyti skatinantys išorinès verslo aplinkos veiksniai: 1) atvira šalies ekonomika, t. y. žemi prekybos barjerai; 2) intensyvi konkurencija šalies verslo šakoje; 3) finansinès paramos teikimas tyrimus ir 


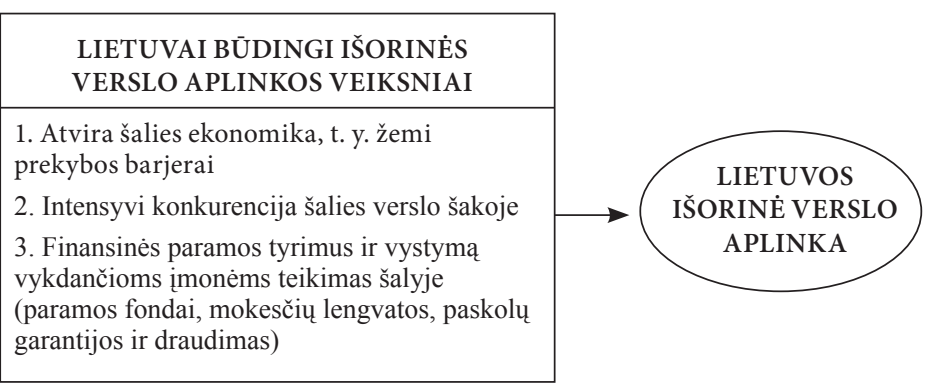

\begin{tabular}{|l|}
\multicolumn{1}{|c}{ LIETUVAI NEBŪDINGI IŠORINĖS } \\
VERSLO APLINKOS VEIKSNIAI \\
1. Klasterių šalies verslo šakoje egzistavimas arba jų \\
formavimasis \\
2. „Profesionalių“ vartotoju šalies verslo šakoje egzistavimas \\
3. Ankstyvos paklausos šalies verslo šakoje \\
egzistavimas \\
4. Istatymai ir kiti teisès aktai, igyvendinantys pakankamą \\
intelektinio turto apsauga šalyje \\
5. Mažas biurokratijos lygis šalyje
\end{tabular}

9 pav. Lietuvos išorinė verslo aplinka Lietuvos „Born Global“ imones inovacijas vykdyti skatinančių išorinès verslo aplinkos veiksnių atžvilgiu

Fig. 9. External business environment of Lithuania in relation to the external business environment factors, which influence the innovation of the Lithuanian "Born Global" companies

vystymą vykdančioms įmonėms šalyje (paramos fondai, mokesčių lengvatos ir paskolų garantijos bei draudimas).

Tyrime dalyvavusių Lietuvos „Born Global“ i̇monių nuomone, Lietuvos išorinei verslo aplinkai nèra būdingi šie penki Lietuvos „Born Global“ imonèse inovacijų vykdymą skatinantys išorinès verslo aplinkos veiksniai: 1) klasterių šalies verslo šakoje egzistavimas arba jų formavimasis; 2) „profesionalių“ vartotojų šalies verslo šakoje egzistavimas; 3) ankstyva paklausa šalies verslo šakoje; 4) ìstatymai ir kiti teisès aktai, igyvendinantys pakankamą intelektinio turto apsaugą šalyje; 5) mažas biurokratijos lygis šalyje.

Tyrimo rezultatai leidžia daryti išvadą, kad Lietuvos išorinëje verslo aplinkoje yra daugiau „Born Global“ imoniu atsiradimui nepalankių išorinès verslo aplinkos veiksnių nei kad palankių. Vis dèlto „Born Global“ imonių atsiradimo klausimas Lietuvoje yra ypač aktualus. Pirma, atsižvelgiant i tai, kad „Born Global“ ịmonès didžiąją dalị savo pajamų gauna iš užsienio šalių, galima daryti išvadą, kad tokių įmonių atsiradimas Lietuvoje galètų teigiamai paveikti Lietuvos užsienio prekybos deficitą, o antra, „Born Global“ imonès dažniausiai yra mažo arba vidutinio dydžio įmonèmis, o smulkusis ir vidutinis verslas vaidina labai svarbų vaidmenị Lietuvos ekonomikoje, pavyzdžiui, sukuria naujas darbo vietas.

Remiantis empirinio tyrimo rezultatais, teiktinas toks pasiūlymas: siekiant sukurti „Born Global“ i̇monių atsiradimui Lietuvoje kuo palankesnę Lietuvos išorinę verslo aplinką, pirmiausia Lietuvos išorinejje verslo aplinkoje turi atsirasti tie „Born Global“ imones inovacijas vykdyti skatinantys išorinès verslo aplinkos veiksniai, kurie, tyrime dalyvavusių Lietuvos „Born Global“ imonių nuomone, nèra būdingi Lietuvos išorinei verslo aplinkai. Antra, labai svarbu, kad tie Lietuvos „Born Global“ imonèse inovacijas vykdyti skatinantys išorinès verslo aplinkos veiksniai, kurie būdingi Lietuvos išorinei verslo aplinkai, nesikeistų, t. y. ir toliau išliktų Lietuvos išorinèje verslo aplinkoje.
Nepaisant to, kad tyrimo rezultatai negali būti pritaikomi pagrindinei visumai, šis tyrimas turi didelę praktinę reikšmę, nes „Born Global“ imonių išorinè verslo aplinka yra nauja, iki šiol Lietuvoje netyrinèta tema, todèl šis tyrimas nubrežia gaires ir suteikia atskaitos tašką ateities tyrinėjimams. Be to, Lietuvos Respublikos valdžios institucijos šio tyrimo rezultatus gali naudoti spręsdamos geresnių Lietuvos išorinès verslo aplinkos sąlygų „Born Global“ ¿̨monèms sukūrimo klausimus, nes atlikto tyrimo rezultatai leidžia sužinoti, kokie Lietuvos „Born Global“ įmonių atsiradimą skatinantys išorinès verslo aplinkos veiksniai nèra būdingi Lietuvai bei, remiantis šia informacija, kryptingai parengti priemonių planą sukurti tuos išorinès verslo aplinkos veiksnius, o po tam tikro laiko atliktų kartotinių tyrimų rezultatai leistų palyginti, kaip Lietuvos išorinè verslo aplinka pasikeitè atsiradus „Born Global“ įmonèms.

\section{Literatūra}

Andersson, S.; Wictor, I. 2003. Innovative internationalisation in new firms: born globals - the Swedish case, Journal of International Entrepreneurship 1: 249-276. doi:10.1023/A:1024110806241

Bell, J.; McNaughton, R. 2000. „Born-global“ firms: a challenge to public policy in support of internationalization, in Marketing in Global Economy. Buenos Aires, Argentina: American Marketing Association, 175-185.

Bessant, J.; Tidd, J. 2007. Innovation and Entrepreneurship. Chichester: J. Wiley. 462 p. ISBN 978-0-470-03269-5.

Dikčius, V. 2003. Marketingo tyrimai: teorija ir praktika. Vilnius: Vilniaus vadybos kolegija. $187 \mathrm{p}$.

Gabrielsson, M.; Kirpalani, V. H. M. 2004. Born globals: how to reach new business space rapidly, International Business Review 13: 555-571. doi:10.1016/j.ibusrev.2004.03.005

Gabrielsson, M.; Kirpalani, V. H. M.; Dimitratos, P.; Solberg, C. A.; Zucchella, A. 2008. Conceptualizations to advance born global definition: a research note, Global Business Review 9(1): 45-50. doi:10.1177/097215090700900103 
Gabrielsson, M.; Sasi, V.; Darling, J. 2004. Finance strategies of rapidly-growing of finnish SMEs: born internationals and born globals, European Business Review 16(6): 590-604. doi:10.1108/09555340410565413

Gankema, H. G. J.; Snuif, H. R.; Zwart, P. S. 2000. The internationalization process of small and medium-sized enterprises: an evaluation of stage theory, Journal of Small Business Management 38: 15-27.

Inovacijų portalas [interaktyvus]. 2009. Všt „Lietuvos inovacijų centras" [žiūrèta 2009 m. gruodžio 20 d.]. Prieiga per internetą: <http://www.inovacijos.lt/index.php?-1853728058>.

Johanson, J.; Vahlne, J. E. 1977. The internacionalization process of the firm - a models of knowledge development and increasing foreign market commitment, Journal of International Business Studies 8(1): 23-32. doi:10.1057/palgrave.jibs.8490676

Kudima, A.; Yip, G. S.; Barkema, H. G. 2008. Born-global, Business Strategy Review 19(4): 39-44.

Lampa, P.; Nilsson, L. 2004. Born Globals - a New Phenomenon in the Field of Internationalisation: Bachelor Dissertation. Kristianstad University College [online], [cited 20 February 2009]. Available from Internet: <http://www.managementheaven.com/born-globals/\#>.

Luostarinen, R.; Gabrielsson, M. 2006. Globalization and marketing strategies of born globals in SMOPECs, Thuderbird International Business Review 48(6): 773-801. doi:10.1002/tie.20122

Madsen, T. K.; Rasmussen, E.; Servais, P. 2000. Differences and similarities between born globals and other types of exporters, Advances in International Marketing 10: 247-265. doi:10.1016/S1474-7979(00)10013-4

Madsen, T. K.; Servais, P. 1997. The internationalization of bornglobals: an evolutionary process?, International Business Review 8: 11-26.

McDougall, P. P.; Oviatt, B. M.; Shrader, R. C. 2003. A comparison of international and domestic new ventures,
Journal of International Entrepreneurship 1: 59-82. doi:10.1023/A:1023246622972

Oviatt, M. B.; McDougall, P. P. 1994. Toward a theory of international new ventures, Journal of International Business Studies 36: 29-41. doi:10.1057/palgrave.jibs. 8400128

Oviatt, M. B.; McDougall, P. P. 1995. Global start-ups: entrepreneurs on a worldwide stage, Academy of Management Executives 9(2): 30-44. doi:10.5465/AME.1995.9506273269

Porter, M. E. 1990. The Competitive Advantage of Nations. New York: Free Press. 855 p. ISBN 0-333-51804-7.

Porter, M. E.; Stern, S. 2001. Innovation: location matter, MIT Sloan Management Review 42(4): 28-36.

Rasmussen, E. S.; Madsen, T. K. 2002. The Born Global Concept, in The 28th EIBA Conference, in the Specials Session "SME Internationalization and Born Globals - Different European Views and Evidence" [interaktyvus]. December 8-10, 2002, Athens University of Economics \& Business, Greece. 96 p. [žiūrèta 2009 m. sausio 25 d.]. Prieiga per internetą: <http://www.sam.sdu.dk/ era/EIBA\%20Rasmussen\%20 2002\%20.pdf>.

Rennie, M. W. 1993. Global competitiveness: born-global, McKinsey Quarterly 4: 45-52.

Rialp, A.; Rialp, J. 2006. Faster and more sucessfful exporters: an exploratory study of born global firms from the resource-based view, Journal of Euromarketing 16(1/2): 71-86. doi:10.1016/j.ibusrev.2004.04.006

Rialp, A.; Rialp, J.; Knight, G. 2005. The phenomenon of early internationalizing firms: what do we know after a decade (1993-2003) of scientific inquiry, International Business Review 14: 147-166.

Saunders, M.; Lewis, P.; Thornhill, A. 2007. Research Methods for Business Students. $4^{\text {th }}$ ed. Harlow: Prentice Hall. 624 p. ISBN 0-273-70148-7.

Vaitkevičius, R.; Saudargienè, A. 2006. Statistika su SPSS psichologiniuose tyrimuose. Kaunas: VDU leidykla. 221 p.

Ramūnas ČASAS. PhD, Associate Professor at Vilnius University (Lithuania), Faculty of Economics, and Department of Marketing. He received his master's degree from Vilnius University in 1995, where he also received his doctoral degree in 2001. His current research interests are: entrepreneurship and internationalization of SME/Born Globals, marketing and branding. He is the author of many scientific articles, and has more than nine years experience in international companies as marketing consultant and manager.

Vilma DAMBRAUSKAITÉ is a graduate student of Vilnius University (Lithuania), Faculty of Economics, where she received Bachelor's degree in business administration in 2008 and a master's degree in international business in 2010. Her current research interests are: international business, external business environment, innovations and entrepreneurship. She is the author of several scientific articles. Currently she is working in telecommunication sector of international company, which is a social partner of master programs at Vilnius University. 